ORDINES MILITARES

COLLOQUIA TORUNENSIA HISTORICA

Yearbook for the Study of the Military Orders

ISSN (print) 0867-2008 / ISSN (online) 2391-7512

\author{
Alan Forey \\ The Bell House \\ Kirtlington \\ Oxon, $\mathrm{OX}_{5}{ }_{3} \mathrm{HJ}$ \\ United Kingdom \\ alan.forey@mybroadbandmail.com
}

\title{
A PROPOSAL FOR THE REFORM OF THE HOSPITAL IN THE LATE THIRTEENTH CENTURY
}

\section{KeVworDs}

Military Orders; Hospitallers; diffinitors; Masters of Military Orders; elections; Trece

I

$\mathrm{n}$ the thirteenth century military orders were often thought to be in need of reform. External criticism frequently focused on the question of their effectiveness in the struggle against the infidel. It was argued that rivalry between orders - especially the Temple and the Hospital - adversely affected their participation in military campaigns: amalgamation was a commonly suggested remedy. ${ }^{1}$ It was further argued that they did not maintain enough troops in frontier regions, and in the fourteenth century it was on several occasions proposed that the Hospital should transfer most of its brothers to the eastern Mediterranean, leaving only a few - mainly ordained brethren and the infirm - in western Europe. ${ }^{2}$ Among

1 A. J. Forey, The Military Orders in the Crusading Proposals of the Late-Thirteenth and Early-Fourteenth Centuries, Traditio 36 (1980), pp. 319-322; H. Nicholson, Templars, Hospitallers and Teutonic Knights. Images of the Military Orders, 1128-1291, Leicester 1993, pp. 74, 122-123.

2 Les registres de Nicolas III (1277-1280), ed. J. Gay, Paris 1898-1938, doc. 167, p. 51; J. Delaville Le Roulx, Cartulaire général de l'ordre des Hospitaliers de Saint-Jean de Jérusalem (henceforth $C H$ ), 4 vols, Paris 1894-1906, here vol. 3, doc. 3674, pp. 372-373; Pierre Dubois, De recuperatione Terre Sancte: Dalla "Respublica Christiana" ai primi nazionalismi e alla politica antimediterranea, ed. A. Diotti, Florence 1977, pp. 126-127; Regestum Clementis papae V, 8 vols, Rome 1885-1892, here vol. 8, doc. 9984, pp. 420-423; Decrees of the Ecumenical Councils, ed. N. P. Tanner, 2 vols, London-Washington 1990, here vol. 1, pp. 355-359; E. Müller,

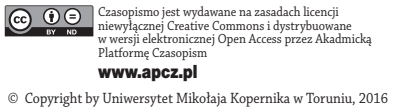


issues covered by internal criticism was the conduct of masters, whose actions were the object of censure in several institutions. In the order of Calatrava, Martin Martínez was apparently forced out of office in the first decade of the thirteenth century $^{3}$ and in I 236 a group of brothers complained to Gregory IX about the conduct of the later master Fernán Pérez. ${ }^{4}$ In I 245 and 1263 attempts were made to depose Pelay Pérez Correa from his post as master of Santiago; 5 and two thirteenth-century masters of the Teutonic order - Gerhard of Malberg and Poppo of Osterna - appear to have been ousted from office. ${ }^{6}$ Such incidents did not usually lead to any major alteration in the governmental structure of an order: in I 246 and I 264 Innocent IV and Urban IV merely confirmed and clarified existing regulations about the deposition of masters in the order of Santiago. ${ }^{7}$ Yet in 1295 , when the Hospitaller master Odo of Pins and some of his predecessors were criticized for failing to abide by the customs and usages of their order, a proposal for a more fundamental change was submitted to the pope by a group of leading Hospitallers, including William of Villaret, prior of St Gilles, and Boniface of Calamandrana, the master deça mer. ${ }^{8}$

It was proposed that a diffinitor should be chosen from each of the order's seven tongues, with the master as the diffinitor for his tongue, and that the government of the Hospital should be entrusted to them, with issues to be decided by a majority. Diffinitors were to be knights, born of lawful marriage, and were to occupy no other post, except command of forces on land or at sea. They were to hold office for life, although they could voluntarily retire at the age of seventy-five; if, however, any diffinitor, including the master, lost his mental faculties he could be

Das Konzil von Vienne, 1311-1312. Seine Quellen und seine Geschichte, Münster 1934, p. 686; L'enquête pontificale de 1373 sur l'ordre des Hospitaliers de Saint-Jean de Jérusalem, ed. A.-M. Legras, Paris 1987, pp. 127-128. In 1318 John XXII instructed military orders in Castile to provide as many men as they could for frontier defence: Jean XXII (1316-1334): Lettres communes, ed. G. Mollat, 16 vols, Paris 1904-1947, here vol. 3, nos 14214-14215, pp. 359-360.

3 C. de Ayala Martínez, Las órdenes militares en el siglo XIII castellano. La consolidación de los maestrazgos, Anuario de estudios medievales 27 (1997), 1, p. 247.

4 Documentos de Gregorio IX (1227-1241) referentes a España, ed. S. Domínguez Sánchez, León 2004, doc. 592, p. 478; J. F. O’Callaghan, Don Fernán Pérez, un maestre desconocido de la orden de Calatrava, 1234-1235, Hispania 43 (1983), pp. 435-436.

5 Ayala Martínez (as n. 3), pp. 267-271; M. López Fernández, Pelay Pérez Correa: historia $y$ leyenda de un maestre santiaguista, Badajoz 2010, pp. 463-468, 476-483.

6 Die Hochmeister des Deutschen Ordens, 1190-2012, ed. U. Arnold, Weimar 2014, pp. 22, 29.

7 López Fernández (as n. 5), docs. 9, 26, 27, pp. 584-585, 607-610; La documentación pontificia de Inocencio IV (1243-1254), ed. A. Quintana Prieto, 2 vols, Rome 1987, here vol. 1, doc. 254, pp. 283-284; La documentación pontificia de Urbano IV (1261-1264), ed. I. Rodríguez de Lama, Rome 1981, doc. 334, pp. 443-444.

$8 \quad C H$ (as n. 2), vol. 3, doc. 4267, pp. 655-657. 
removed from office by the other diffinitors. Masters and diffinitors could also be deprived of office if they were guilty of heresy, persistent perjury, murder, sodomy or deserting to the Muslims. Diffinitors who were repeatedly found to be perverse and contentious by the master and all the other diffinitors could also be removed from office. The wording of this last proposal does not indicate clearly whether it was meant to apply to the master as well as to other diffinitors, but it could be interpreted in that sense. Vacancies among the diffinitors were to be filled by the master and the remaining diffinitors, while new masters were to be elected by the diffinitors and by seven other brothers, who might include priests and sergeants. These seven electors were to be chosen by the convent and bailiffs, but if they were not named within a set time limit, the choice of master was to rest with the diffinitors. Newly-appointed masters and diffinitors were to swear an oath which included an undertaking to abide by the rule and customs of the order.

Not all these proposals were completely without precedent in the Hospital. An oath to observe the Hospital's rule and customs had been required of the master by Alexander III in I 172 and also by the statutes enacted at Margat in the early thirteenth century. ${ }^{9}$ Nor was this the first occasion when procedures had been proposed for limiting the master's freedom of action: in I 278 it had been decreed in the general chapter that documents relating to certain important issues, such as gifts, sales, exchanges and the recall of certain officials, should be sealed with a new seal of the master and convent; it was to be kept by the treasurer under the seals of the grand preceptor, marshal and hospitaller, as well as of the master. ${ }^{10}$ Offences such as heresy, sodomy and desertion to the Muslims were already punishable by expulsion from the order. ${ }^{11}$ Those who became knights in the Hospital were in the thirteenth century expected to be of lawful marriages, ${ }^{12}$ and the most important posts in the Hospitaller central convent were normally filled by knights.

Yet clearly a major restructuring of government was being envisaged. Although the master had in the past been expected to take counsel and although some issues, such as appointments to leading offices, had been reserved to the order's general chapter, the Hospital was now to be subjected to a self-perpetuating oligarchy, which would decide issues by a majority vote, so that the master's standing would be much reduced. Although before 1295 a master who had committed offences such as heresy or sodomy would have been expelled from the order, this is the first time that the right to depose a master, at least in certain circumstances, was

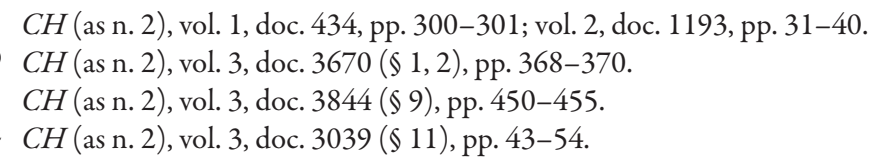


claimed. Admittedly in 1299 the convent asserted that Afonso of Portugal had been deposed in the early thirteenth century, but this claim was made at a time when the convent was trying to put pressure on the master William of Villaret to travel out to the East; and the various versions of the Chronica defunctorum magistrorum state or imply that he resigned. ${ }^{13}$ Later, in 1317 , the convent sought to justify its attempt to depose Fulk of Villaret and to elect a new master by asserting that, according to the statutes and customs of the order, power and jurisdiction rested ultimately with the convent; but it could not quote any ruling which gave it authority to depose a master. ${ }^{14}$ Although support for the convent's claim was given by the jurist Oldradus of Ponte, who asserted that the convent had in the past threatened to depose absent masters, ${ }^{15}$ it was rejected by John XXII, who reinstated Fulk. ${ }^{16}$ As diffinitors were to hold no other office, the role of the existing leading officials in the central convent, who had until then advised the master, would also become more restricted. Possibly the reformers in this context were influenced by the fact that in recent years the convent had done little to check the activities of masters: the statutes issued in the chapter general held in September I 294, for example, contain no criticism of Odo of Pins's conduct. ${ }^{17}$ Another consequence was that the role of chaplains and sergeants in the government of the order was to be further limited, for whereas the thirteen brothers who had elected masters in the past had to include at least one chaplain and one sergeant, ${ }^{18}$ the inclusion of

13 CH (as n. 2), vol. 3, doc. 4662, pp. 769-776; W. Dugdale, Monasticon anglicanum, 6 vols, London 1817-1830, here vol. 6, p. 797; Estatutos de la orden de San Juan de Jerusalén. Edición critica de los manuscritos occitanos (S. XIV), ed. M. R. Bonnet, R. Cierbide, Bilbao 2006, pp. 285, 298, 302; A. Luttrell, Afonso of Portugal, Master of the Hospital: 1202/3-1206, in: Deeds done beyond the Sea: Essays on William of Tyre, Cyprus and the Military Orders presented to Peter Edbury, ed. S. B. Edgington, H. Nicholson, Farnham 2014, p. 206; see also Paris, Bibliothèque Nationale, MS Fr. 6049, fol. 233r.

14 Vatikanische Akten zur deutschen Geschichte in der Zeit Kaiser Ludwigs des Bayern, ed. S. Riezler, Innsbrick 1891, doc. 70, pp. 52-54.

15 Oldradus de Ponte, [Consilia], Rome 1472, no. 128. He referred only to Fulk of Villaret by name.

16 A. Luttrell, Notes on Foulques de Villaret, Master of the Hospital, 1305-1319, in: Guillaume de Villaret $1^{\text {er }}$ Recteur du Comtat Venaissin 1274 Grand Maître de l' ordre des Hospitaliers de SaintJean de Jérusalem, Chypre 1296, Paris 1985, p. 77. The date of Fulk's reinstatement is usually given as 1319, but the Aragonese king James II knew of it by October 1318: Barcelona, Archivo de la Corona de Aragón, Cancillería Real, Registro 338, fol. 18r-18v. When Fulk ceased holding the office of master in 1319 it was stated that he had resigned of his own free will: S. Pauli, Codice diplomatico del sacro militare ordine Gerosolimitano, oggi di Malta, 2 vols, Lucca 1733-1737, here vol. 2, doc. 55, p. 73.

$17 C H$ (as n. 2), vol. 3, doc. 4259, pp. 650-652.

$18 C H$ (as n. 2), vol. 2, doc. 1193, pp. 31-40. 
brothers of these ranks was to become optional, and there was provision for the election to be decided in some circumstances solely by the knightly diffinitors.

Although major changes in the government of the Hospital were being envisaged, it has been maintained that, when viewed against developments in other religious orders, the proposals were not very original. ${ }^{19}$ The office of diffinitor is certainly encountered in many religious orders in the thirteenth century, but in these institutions diffinitors usually constituted merely a committee which functioned during general or, more rarely, provincial chapters. In the Dominican order, provincial chapters elected four brothers to act as diffinitors. ${ }^{20}$ According to Cistercian statutes issued in I 197 the abbot of Cîteaux was to nominate the four senior abbots and an unspecified number of others to act as diffinitors at his order's general chapter, while in 1265 a more elaborate procedure was devised for the appointment of twenty-five diffinitors. ${ }^{21}$ Similar arrangements relating to general chapters existed in other religious orders. ${ }^{22}$ The purpose was to facilitate decision-making in large assemblies: the work of a chapter was delegated to a committee, which exercised wide-ranging powers, especially in general chapters, where diffinitors commonly made legislative, judicial and administrative decisions. It should also be noted, however, that new diffinitors were usually chosen at each chapter, and that their powers were normally exercised only during chapters, although when in 1233 reforming decrees were drawn up for the order of Arrouaise it was stated that the abbot and two of the diffinitors were to visit the order's houses and ensure that recent reforms were being implemented; and this became a regular practice in that order. ${ }^{23}$

It could, however, be suggested that there were similarities between the proposed Hospitaller diffinitors and the council of thirteen - the Trece - which had

19 J. Riley-Smith, The Knights Hospitaller in the Levant, c.1070-1309, Basingstoke 2012, p. 136.

20 G. R. Galbraith, The Constitution of the Dominican Order, 1216-1360, London 1925, pp. 38, 71; W. A. Hinnebusch, The History of the Dominican Order, 2 vols, New York 1965, here vol. 1, p. 186.

21 Twelfth-Century Statutes from the Cistercian General Chapter, ed. C. Waddell, Cîteaux 2002, pp. 17-18, 400-401; J. M. Canivez, Statuta capitulorum generalium ordinis Cisterciensis ab anno 1116 ad annum 1786, 8 vols, Louvain 1933-1941, here vol. 3, pp. 26-27; J.-B. Mahn, L'ordre cistercien et son gouvernement: des origines au milieu du XIII siècle (1098-1265), Paris 1951, pp. 190-193.

22 J. Hourlier, Le chapitre général jusquiau moment du grand schisme, Paris 1936, pp. 226-234; H. E. Salter, Chapters of the Augustinian Canons, Canterbury and York Society, vol. 29, London 1922, pp. xv, 144-146; L. Milis, L’ordre des chanoines reguliers d'Arrouaise, Bruges 1969, pp. 565-573.

23 Milis (as n. 22), pp. 239, 241, 252, 572, 577-578; Monumenta Arroasiensia, ed. B.-M. Tock, Corpus Christianorum, Continuatio Mediaevalis, vol. 175, Turnhout 2000, docs. 296, 316, 328, pp. 471-472, 499-500, 509-510. 
existed in the order of Santiago since the I I 70s. This was a body which was expected to counsel the master and had the power both to elect and to depose him. ${ }^{24}$ Alexander III's confirmation of Santiago in I 175 and the order's rule also stated that when a member of the Trece died or was removed from office because of an offence or for any other reason the master was to fill the vacancy with the advice of the remaining members of the council: this does not suggest that membership was a limited, short-term appointment. ${ }^{25}$ Yet members of the Trece were warned that they should be obedient to the master and they were expected to give counsel only when there was need (cum opus fuerit), although in practice there were occasions when members of the Trece sought to exceed their advisory function. ${ }^{26}$ Unlike the proposed diffinitors in the Hospital, they normally also held other posts, whether as comendadores mayores or as commanders in various parts of the Iberian peninsula, which meant that it would have been impossible constantly to assemble a full council to advise the master. Nor is there any reason to suppose that the Hospitaller reformers were aware of arrangements in the order of Santiago.

Those who proposed the changes in the Hospital in I 295 may have been influenced in part by personal considerations. William of Villaret may have seen the leadership of an opposition movement as a means of furthering his own career. $\mathrm{He}$ certainly showed no interest in implementing the proposed reforms after he had been elected master in 1296 following the death of Odo of Pins. In I 295 the Aragonese King James II had also complained to the pope and to Charles II of Naples about Odo of Pins's displeasure (despagament) with Boniface of Calamandrana. ${ }^{27}$ No details were given, but as the comment was made by the Aragonese king, it may well have been that the Hospitaller master was critical of Boniface's heavy involvement in negotiations about the Sicilian problem, which must have limited

24 J. L. Martín, Orígenes de la orden militar de Santiago (1170-1195), Barcelona 1974, doc. 73, pp. 248-254; Documentos pontificios referentes a la diócesis de León (siglos XI-XIII), ed. S. Domínguez Sánchez, León 2003, doc. 43, pp. 103-106; D. W. Lomax, La orden de Santiago (1170-1275), Madrid 1965, p. 227; E. Gallego Blanco, The Rule of the Spanish Military Order of St. James, 1170-1493, Leiden 1971, pp. 121-122.

25 Evidence is insufficient to ascertain how long members of the Trece were normally in office in the twelfth and thirteenth centuries, although some thirteenth-century decrees of general chapters list members of the Trece: López Fernández (as n. 5), doc. 1, pp. 561-577; P. Josserand, Eglise et pouvoir dans la Péninsule Ibérique. Les ordres militaires dans le royaume de Castille (1252-1369), Madrid 2004, pp. 835-850; see also Marqués de Siete Iglesias, Los trece de la orden de Santiago. Catálogo biográfico, Hidalguía 27 (1979), pp. 524-529.

26 J. V. Matellanes Merchán, La estructura de poder en la orden de Santiago, siglos XII-XIV, En la España medieval 23 (2000), p. 298; M. Rivera Garretas, La encomienda, el priorato y la villa de Uclés en la edad media (1174-1310), Madrid-Barcelona 1985, doc. 180, pp. 382-383.

27 H. Finke, Acta Aragonensia, 3 vols, Berlin 1908-1922, here vol. 3, doc. 20, p. 39. 
the time he could spend on the order's affairs. ${ }^{28}$ But the proposals were not merely the work of a few individuals with personal grievances. That there was widespread discontent with the actions of Odo of Pins and other masters is implied by William of San Stefano's comment in the compilation, which he completed a few years later, that the proposal was supported by some other bailiffs appointed by the chapter general and by other long-serving brothers. ${ }^{29}$ Discontent with the actions of Odo and some of his predecessors was also expressed in the letter sent to William of Villaret by the convent in Cyprus shortly after his election in I 296;30 and William of San Stephano himself wrote that in Odo's time the order was in "a poor state because of his unsatisfactory conduct". ${ }^{31}$ A very similar comment is found in versions of the Chronica defunctorum magistrorum..$^{32}$ Opposition was by no means limited to a few Hospitallers in the West.

It is often difficult to discover in detail how the actions of masters of military orders provoked criticism. Discontent in Calatrava in 1236 is known only from the letter in which Gregory IX delegated two bishops to investigate, and the pope provided no precise information about the nature of the complaints against Fernán Pérez; $;^{33}$ and the events leading to the creation of a new seal in the Hospital in 1278 are not recorded in surviving sources. But the letter of the Hospitaller convent to William of Villaret in I 296 does list some of the abuses which had occurred in the time of Odo of Pins and his predecessors, including the recalling of priors before the due term, the by-passing of priors when orders were issued and the retention of priories and houses by masters as chambers: heads of the order had been ignoring accepted usages in matters concerning the relations between the order's headquarters and priories. It was further complained that excessive financial

28 For an alternative suggestion, see J. Burgtorf, A Mediterranean Career in the Late Thirteenth Century: The Hospitaller Grand Commander Boniface of Calamandrana, in: The Hospitallers, the Mediterranean and Europe. Festschrift for Anthony Luttrell, ed. K. Borchardt, N. Jaspert, H. J. Nicholson, Aldershot 2007, p. 82.

29 MS Fr. 6049 (as n. 13), fol. 255r; published in a note in $C H$ (as n. 2), vol. 3, p. 655. On William of San Stefano, see L. Delisle, Maître Jean d'Antioche, traducteur, et frère Guillaume de Saint-Etienne, hospitalier, in: Histoire littéraire de la France, vol. 33, Paris 1906, pp. 24-40; A. Luttrell, The Hospitallers' Early Written Records, in: The Crusades and their Sources: Essays presented to Bernard Hamilton, ed. J. France, W. G. Zajac, Aldershot 1998, pp. 135-154; J. Burgtorf, Die Pariser Sammlung des Johanniters Wilhelm von St. Stefan: Bibliothèque Nationale, fonds français 6049 (ms. s. XIV), in: Die Rolle der Schriftlichkeit in den geistlichen Ritterorden des Mittelalters, ed. R. Czaja, J. Sarnowsky (Ordines Militares. Colloquia Torunensia Historica XV), Toruń 2009, pp. 253-276.

30 CH (as n. 2), vol. 3, doc. 4310, pp. 681-683.

31 Mal estat por son descoveignable portement: MS Fr. 6049 (as n. 13), fol. $244 \mathrm{v}$.

32 Dugdale (as n. 13), vol. 6, p. 797; Estatutos de la orden de San Juan (as n. 13), pp. 299, 304-305.

33 Documentos de Gregorio IX (as n. 4), doc. 592, p. 478. 
demands had been made on priories, while masters themselves had indulged in lavish expenditure. The list provided in the letter is not comprehensive, but there is nothing to suggest that the crisis was linked with the collapse of the crusader states. The proposal was made four years after the fall of Acre, and reference to the misdeeds of several masters indicates that abuses were thought to have begun well before I29I.

The Hospitaller proposals put forward in 1295 were, however, never implemented. William of San Stefano reported that after William of Villaret had left the papal court to attend to other business enthusiasm had waned amongst his colleagues. ${ }^{34}$ In August 1295 Boniface VIII merely instructed Odo of Pins to mend his ways; and the statutes drawn up in the general chapter in the following month include nothing about the master's position. ${ }^{35}$ And in the closing years of the thirteenth century not only did William of Villaret after becoming master make no attempt to implement the proposals: when the convent wrote to him shortly after his appointment in I 296, pointing out the errors of his predecessors, they merely requested him to promise to observe the rules and customs of the Hospital. The convent made no reference to diffinitors. ${ }^{36}$ The conflict between the convent and the master in 1299 when William of Villaret planned to hold a general chapter at Avignon and when he had still not travelled out to the East similarly did not lead to a revival of demands for diffinitors: the convent merely requested, in accordance with Hospitaller customs, a judgement (esgart) on their claim that the master could not summon a general chapter to meet in western Europe. ${ }^{37}$ When there was opposition to the next master, Fulk of Villaret, in the second decade of the fourteenth century, a solution was sought by attempting to depose him rather than by altering the structure of government. ${ }^{38}$

A strong monarchical form of government seems in fact to have been normally accepted in the Hospital. When writing to William of Villaret in 1299 the convent repeatedly referred to him as their father or spiritual father and to themselves as his children; and their envoys were enjoined to show respect and courtesy to him. ${ }^{39}$ When masters were acting improperly attempts might be made to impose permanent restrictions, as happened in 1278 as well as in 1295 , but in practice there seems to have been little desire to subject him in the long term to close super-

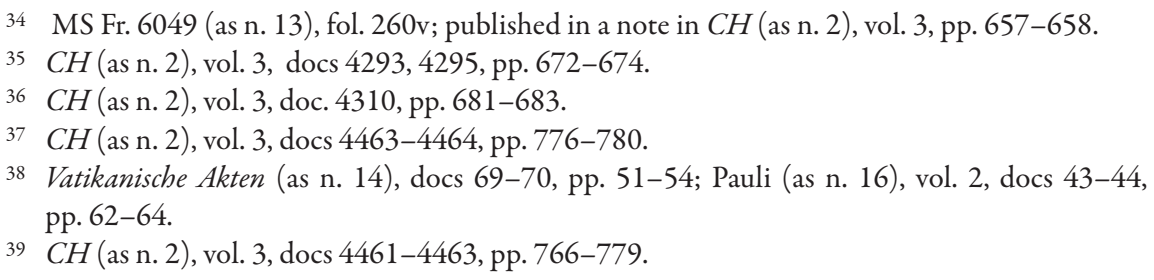


vision. In $\mathrm{I} 3 \mathrm{O}_{2}$ it was ruled that documents which bore the seal of the master and convent should be sealed in the presence of the grand preceptor, the marshal, the hospitaller and treasurer. ${ }^{40}$ These officials, under whose seals the seal of the master and convent was kept, appear not to have maintained a close check on the use of the seal. The complaints made in the 1290 s, which alluded to the actions of several masters, would also imply that the latter had been allowed considerable freedom of action. It was this attitude that prompted William of San Stefano, when commenting on the letter sent by the convent to William of Villaret in I 296, to state that "those who tolerate evils and endure them in silence will be punished before God, and those who repress them in due manner will receive God's praise". ${ }^{4}$

The Hospitallers' general reluctance to impose lasting restrictions on the master's freedom of action was not an unusual stance in the later thirteenth and early fourteenth centuries. Parallels may be drawn with what happened in the secular government of various states at times when royal policies were unpopular and unsuccessful. Measures were certainly taken, as in the Hospital, to ensure that rulers acted with advice and consent, especially on certain issues. There were in the first place demands that parliamentary assemblies should meet at regular intervals. In England the Provisions of Oxford in I 258 required Henry III to summon three parliaments a year, and in I 3 I I Edward II had to accept the Ordainers' decree that parliament should meet at least once and, if necessary, twice a year. ${ }^{42}$ In I 283 Peter III similarly had to agree to annual meetings of the cortes in Aragon and Catalonia, and a similar concession was made in Catalonia by James II in I 300 , while a demand for annual parliaments was also voiced in Sicily in $\mathrm{I} 296.43$ In some instances there was also a requirement that certain matters should be decided only in assemblies: that war should be waged only with parliamentary assent was demanded in Aragon in I283, in Sicily in 1296 and in England in I3 I I. ${ }^{44}$ Such requirements were in addition to the accepted notion that extraordinary taxation,

$40 C H$ (as n. 2), vol. 4, doc. 4574 (\$11), pp. 36-41.

41 Ceaus que les maus soffrent et passent taisiblement seront puni devant dieu, et qui les reprent selonc debue maniere en auront bon merite de dieu: Ms Fr. 6049 (as n. 13), fol. 254v; published in Delisle (as n. 29), pp. 31-32.

42 Documents of the Baronial Movement of Reform and Rebellion, 1258-1267, ed. R. F. Treharne, I. J. Sanders, Oxford 1973, pp. 96-112; Statutes of the Realm, 12 vols, London 1810-1828, here vol. 1, pp. 157-167.

43 L. González Antón, Las uniones aragonesas y las cortes del reino (1282-1301), 2 vols, Zaragoza 1975, here vol. 2, pp. 14-19; Cortes de los antiguos reinos de Aragón y de Valencia y principado de Cataluña, 26 vols, Madrid 1896-1922, here vol. 1, pp. 140-153, 167-180; A. Marongiu, Medieval Parliaments: a Comparative Study, London 1968, p. 116.

44 Statutes of the Realm (as n. 42), vol. 1, pp. 157-167; González Antón (as n. 43), vol. 2, pp. 14-19; Marongiu (as n. 43), p. 116. 
to which a ruler had no right, should not be imposed without consent. Although demands were at times repeated - unlike the Hospitaller proposal for the creation of diffinitors - reforms of this kind in secular government were in practice short-lived and of little long-term significance. In some instances concessions were later formally annulled, as in England in the Dictum of Kenilworth in 1266 and the Statute of York in $1322,{ }^{45}$ but there was in fact little support for permanent constraints on a monarch who was thought to rule by God's grace. Concessions made in times of crisis could quickly be ignored without provoking immediate opposition. Despite the undertaking to hold annual assemblies, the Aragonese cortes was not summoned in the years from I 292 to I 299, and that of Catalonia was not assembled for eight years after I 292. In the whole of James II's reign of thirty-six years from I 29I until I 327 the Aragonese cortes met only nine times. ${ }^{46}$ Discontent could occasion attempts to place restrictions on a monarch's freedom of action, but once the immediate crisis was past, these restraints tended to be forgotten. In the same way, the plan to place the government of the Hospital in the hands of seven diffinitors had no lasting consequences for the Hospital's governmental structure.

\section{SOURCES AND Literature}

Bonnet, Marie R., Cierbide, Ricardo., edit. "Estatutos de la orden de San Juan de Jerusalén. Edición crítica de los manuscritos occitanos (S. XIV)." Bilbao: Universidad del País Vasco, 2006.

Canivez, Joseph-Marie., edit. "Statuta capitulorum generalium ordinis Cisterciensis ab anno I I 6 ad annum I786." 8 vols. Louvain: Bureaux de la Revue, I933-I94I.

"Cortes de los antiguos reinos de Aragón y de Valencia y principado de Cataluña." 26 vols. Madrid: Real Academia de la Historia, r 896-1922.

Delaville Le Roulx, Joseph., edit. "Cartulaire général de l'ordre des Hospitaliers de SaintJean de Jérusalem.” 4 vols. Paris: Leroux, I 894-1906.

Domínguez Sánchez, Santiago., edit. "Documentos de Gregorio IX (I227-I24I) referentes a España." León: Universidad de León, 2004.

Domínguez Sánchez, Santiago., edit. "Documentos pontificios referentes a la diócesis de León (siglos XI-XIII).” León: Universidad de León, 2003.

45 Documents of the Baronial Movement (as n. 42), pp. 326-336; Statutes of the Realm (as n. 42), vol. 1, pp. 189-190.

46 L. González Antón, Las Cortes aragonesas en el reinado de Jaime II, Anuario de historia del derecho español 47 (1977), pp. 571, 577-578; Cortes de los antiguos reinos de Aragón y de Valencia $y$ principado de Cataluña (as n. 43), vol. 1, pp. 154, 167. 
Diotti, Angelo., edit. Pierre Dubois. "De recuperatione Terre Sancte: Dalla "Respublica Christiana" ai primi nazionalismi e alla politica antimediterranea." Florence: Olschki, I 977.

Dugdale, William., edit. "Monasticon anglicanum." 6 vols. London: Longman, i 8 I 7 - I 830. Finke, Heinrich., edit. "Acta Aragonensia." 3 vols. Berlin: Rothschild, I 908 -1 922.

Gay, Jules., edit. Les Registres de Nicolas III (I277-I280). Paris: A. Fontemoing, I 898- I 938.

Mollat, Guillaume., edit. "Jean XXII (I 3 I6-1334): Lettres communes.” I6 vols. Paris: A. Fontemoing, I 904-1 947.

Oldradus de Ponte. “Consilia.” Rome: Adam Rot, I 472.

Quintana Prieto, Augusto., edit. "Documentación pontificia de Inocencio IV (I $243-$ -I 254).” 2 vols. Rome: Instituto Español de Historia Eclesiástica, I 987.

Pauli, Sebastiano., edit. "Codice diplomatico del sacro militare ordine Gerosolimitano, oggi di Malta.” 2 vols. Lucca: Salvatore e Giandomenico Marescandoli, I733$-1737$.

"Regestum Clementis papae V”. 8 vols. Rome: Typographia Vaticana, i 88 5- I 892.

Riezler Sigmund., edit. "Vatikanische Akten zur deutschen Geschichte in der Zeit Kaiser Ludwigs des Bayern.” Innsbrick: Königlich Bayerische Akademie der Wissenschaften. Historische Kommission, Wagner, I 89 I.

Rodríguez de Lama, Ildefonso., edit. "Documentación pontificia de Urbano IV (I 26 II 264).” Rome: Instituto Español de Historia Eclesiástica, I 98 I.

Salter, H. E., edit. "Chapters of the Augustinian Canons." Vol. 29. London: Canterbury and York Society, 1922.

"Statutes of the Realm." I 2 vols. London: Record Commission, I 8 I O- I 828.

Tanner, Norman P., edit. Decrees of the Ecumenical Councils. 2 vols. London, Washington: Sheed and Ward, Georgetown University Press, I 990.

Tock, Benoît-Michel., edit. "Monumenta Arroasiensia." In Corpus Christianorum. Continuatio Mediaevalis. Vol. 175. Turnhout: Brepols, 2000.

Treharne, Reginald F., Sanders, Ivor J., edit. "Documents of the Baronial Movement of Reform and Rebellion, I 258-I 267." Oxford: Clarendon Press, i 973.

Waddell, Chrysogonus., edit. Twelfth-Century Statutes from the Cistercian General Chapter. Cîteaux: Commentarii cistercienses, 2002.

Arnold, Udo., edit. Die Hochmeister des Deutschen Ordens, IIgo-20I2. Weimar: Verlag und Datenbank für Geisteswissenschaften, 20 I 4.

Ayala Martínez, Carlos de. Las órdenes militares en el siglo XIII castellano. La consolidación de los maestrazgos, Anuario de estudios medievales 27 ( I 997), I: 239-279.

Burgtorf, Jochen. "A Mediterranean Career in the Late Thirteenth Century: The Hospitaller Grand Commander Boniface of Calamandrana." In The Hospitallers, the Mediterranean and Europe. Festschrift for Anthony Luttrell, edited by Karl Borchardt, Nikolas Jaspert and Helen J. Nicholson, 73-85, Aldershot: Ashgate, 2007.

Burgtorf, Jochen. "Die Pariser Sammlung des Johanniters Wilhelm von St. Stefan: Bibliothèque Nationale, fonds français 6049 (ms. s. XIV)." In Die Rolle der Schriftlichkeit 
in den geistlichen Ritterorden des Mittelalters, edited by Roman Czaja and Jürgen Sarnowsky, 253-276. Toruń: Wydawnictwo Naukowe Uniwersytetu Mikołaja Kopernika, 2009.

Delisle, Léopold. "Maître Jean d'Antioche, traducteur, et frère Guillaume de Saint-Etienne, hospitalier." In Histoire littéraire de la France. Vol. 33, I -40, Paris: Imprimerie nationale, 1906.

Forey, Alan J. The Military Orders in the Crusading Proposals of the Late-Thirteenth and Early-Fourteenth Centuries, Traditio 36 (1980): 3 1 7-345.

Galbraith, Georgina R. The Constitution of the Dominican Order, $1216-1360$, London: Manchester University Press, I 925.

Gallego Blanco, Enrique. The Rule of the Spanish Military Order of St. James, II70-I493. Leiden: Brill, I 97 I.

González Antón, Luis. "Las Cortes aragonesas en el reinado de Jaime II." Anuario de historia del derecho español 47 (1977): 523-682.

González Antón, Luis. Las uniones aragonesas y las cortes del reino (I282-I30I). 2 vols. Zaragoza: Consejo Superior de Investigaciones Científicas, Escuela de Estudios Medievales, I975.

Hinnebusch, William A. The History of the Dominican Order. 2 vols. New York: Alba House, 1965 .

Hourlier, Jean. Le chapitre général jusquiau moment du grand schisme. Paris: Recueil Sirey, 1936.

Josserand, Philippe. Eglise et pouvoir dans la Péninsule Ibérique. Les ordres militaires dans le royaume de Castille (I252-1369), Madrid: Casa de Velázquez, 2004.

Legras, Anne-Marie., edit. L'enquête pontificale de 1373 sur l'ordre des Hospitaliers de SaintJean de Jérusalem. Paris: Centre national de recherche scientifique, i 987.

Lomax, Derek W. La orden de Santiago (II70-I275). Madrid: Consejo Superior de Investigaciones Científicas, Escuela de Estudios Medievales, 1965.

López Fernández, Manuel. Pelay Pérez Correa: historia y leyenda de un maestre santiaguista. Badajoz: Diputación de Badajoz, 20 Io.

Luttrell, Anthony. "Afonso of Portugal, Master of the Hospital: 1 202/3-1 206." In Deeds done beyond the Sea: Essays on William of Tyre, Cyprus and the Military Orders presented to Peter Edbury, edited by Susan B. Edgington and Helen Nicholson, 1 97-206. Farnham: Ashgate, 2014.

Luttrell, Anthony. "Notes on Foulques de Villaret, Master of the Hospital, I 305 - I 3 1 $9 . "$ In Guillaume de Villaret I ${ }^{\text {er }}$ Recteur du Comtat Venaissin 1274 Grand Maître de l'ordre des Hospitaliers de Saint-Jean de Jérusalem, Chypre 1296, 73-90. Paris: Conseil international de la langue française, 1985 .

Luttrell, Anthony. "The Hospitallers' Early Written Records." In The Crusades and their Sources: Essays presented to Bernard Hamilton, edited by John France and William G. Zajac, I 35-I 54. Aldershot: Ashgate, 1998.

Mahn, Jean-Berthold. L'ordre cistercien et son gouvernement: des origines au milieu du XIII ${ }^{e}$ siècle (1008-1265). Paris: Boccard, I 95 I. 
Marongiu, Antonio. Medieval Parliaments: a Comparative Study. London: Eyre \& Spottiswoode, I 968.

Martín, José-Luis. Orígenes de la orden militar de Santiago (II70-II95). Barcelona: Consejo Superior de Investigaciones Científicas, I 974.

Matellanes Merchán, José V. "La estructura de poder en la orden de Santiago, siglos XII-XIV." En la España medieval 23 (2000): 293-3 19.

Milis, Ludovicus. L'ordre des chanoines reguliers d'Arrouaise. Bruges: De Tempel, 1969.

Müller, Ewald. Das Konzil von Vienne, I3II-I3I2. Seine Quellen und seine Geschichte. Münster: Aschendorff, 1934.

Nicholson, Helen. Templars, Hospitallers and Teutonic Knights. Images of the Military Orders, II 28-I29I. Leicester: Leicester University Press, I 993.

O’Callaghan, Joseph F. "Don Fernán Pérez, un maestre desconocido de la orden de Calatrava, I 234-I 235." Hispania 43 ( I 983): 433-439.

Riley-Smith, Jonathan. The Knights Hospitaller in the Levant, c. 1070-1309. Basingstoke: Palgrave Macmillan, 20 I 2.

Rivera Garretas, María-Milagros. La encomienda, el priorato y la villa de Uclés en la edad media (II74-I310). Madrid-Barcelona: CSIC Press, i 985.

Siete Iglesias, Marqués de. "Los trece de la orden de Santiago. Catálogo biográfico." Hidalguía 27 (1979): 523-597.

\section{Abstract \\ A proposal for the Reform of the Hospital in the Late Thirteenth Century}

Although opposition to masters was voiced in several military orders in the thirteenth century, the criticism expressed in the Hospital in 1295 was unusual in that an attempt was made to alter the order's structure of government. It was claimed that masters had not observed the rule and customs of the order, and the Hospital was therefore to be placed under the control of seven diffinitors, of whom the master was to be one, and who were to hold office for life: they were to constitute a self-perpetuating oligarchy. Their proposed powers were to be noticeably greater than those of diffinitors of other religious orders, as the latter usually exercised authority only during provincial or general chapters. Support for the scheme quickly waned, however, and it was not implemented; nor was any attempt made later to revive it. Its failure reflects the widespread acceptance of a strong monarchical form of government, and can be compared with the failure of measures taken in various countries during the late thirteenth and early fourteenth centuries to restrict the independence of secular rulers when these were pursuing policies which were unpopular or unsuccessful. 